\title{
Development of bioactive films based on chitosan and Cynara cardunculus leaves extracts for wound dressings
}

\author{
Teresa Brás ${ }^{\mathrm{a}, \mathrm{b}}$, Daniela Rosa ${ }^{\mathrm{a}, \mathrm{c}, \mathrm{d}}$, Ana C. Gonçalves ${ }^{\mathrm{e}}$, Andreia C. Gomes ${ }^{\mathrm{e}}$, Vítor D. Alves ${ }^{\mathrm{f}}$, João G. Crespo ${ }^{\mathrm{b}}$, \\ Maria F. Duarte ${ }^{\mathrm{a}, \mathrm{d}}$, Luísa A. Neves ${ }^{\mathrm{b}, *}$ \\ ${ }^{a}$ Centro de Biotecnologia Agrícola e Agro-Alimentar do Alentejo (CEBAL)/Instituto Politécnico de Beja (IPBeja), 7801-908 Beja, Portugal \\ ${ }^{\mathrm{b}}$ LAQV/REQUIMTE, FCT-Universidade Nova de Lisboa, Campus de Caparica, 2829-516 Caparica, Portugal \\ c Allelopathy Group, Department of Organic Chemistry, INBIO Institute of Biomolecules, Campus de Excelencia Internacional Agroalimentario (ceiA3), University of Cádiz, 11510 Puerto Real, Cádiz, \\ Spain \\ d MED - Mediterranean Institute for Agriculture, Environment and Development, CEBAL, 7801-908 Beja, Portugal \\ e CBMA - Centre of Molecular and Environmental Biology, Department of Biology, University of Minho, Campus of Gualtar, 4710-057 Braga, Portugal \\ ${ }^{\mathrm{f}}$ LEAF, Linking, Landscape, Environment, Agriculture and Food, Instituto Superior de Agronomia, Universidade de Lisboa, Tapada da Ajuda, 1349-017 Lisboa, Portugal
}

A R T I C L E I N F O

\section{Article history:}

Received 31 July 2020

Received in revised form 11 September 2020

Accepted 15 September 2020

\section{Keywords:}

Chitosan films

Cynara cardunculus extracts

Cynaropicrin

Wound dressing

Skin inflammation
Available online 19 September 2020

\begin{abstract}
A B S T R A C T
The development of natural based, effective and protective wound dressings associated to local treatment applied on chronic wounds, represents a major challenge nowadays. In this work chitosan-based films were prepared with different concentrations of ethanolic ultrasound assisted extracts from Cynara cardunculus leaves (EtPUAE). The physico-chemical film properties revealed that extract incorporation influences the volumetric swelling capacity and mechanical properties of the films, leading to materials with a lower fluid absorption capacity and more fragile. However, no impact was detected on the thermal properties of the films, as well as on their dense structure characterized by Scanning Electronic Microscopy (SEM) analysis. Biological screening of chitosan-based films show that chitosan with a 1\% (w/w) and a 5\% (w/w) EtPUAE loading did not induce cytotoxicity on normal human skin fibroblasts (Bj5-ta cell line), mainly attributed to cynaropicrin (extract key active compound) present in the film below its $\mathrm{IC}_{50}$ value. Nevertheless, chitosan-based films with $5 \%(\mathrm{w} / \mathrm{w}) \mathrm{EtPUAE}$ presented an interesting anti-inflammatory activity. Bj5-ta cells stimulated with liposaccharides (LPS), presented a reduction of $86 \%$ on IL- 6 cytokine levels, after exposure to chitosan with $5 \%$ EtPUAE film extract.

The results obtained in this study open up the possibility of successfully using chitosan films doped with EtPUAE for development of chronic wound dressings, with the advantage of using naturally-sourced materials with antiinflammatory activity.
\end{abstract}

\section{Introduction}

Defined as a disruption resultant from physical or thermal damage, in the continuity of the epithelial lining of the skin or mucosa, a wound can be defined as acute or chronic according to its healing time [1]. Comprising a dynamic and complex process of tissue regeneration and growth, wound healing progresses through four different phases: coagulation and haemostasis, inflammation, proliferation and maturation [2]. Chronic wounds fail to progress through the normal stages of the healing cascade and are not repaired in an orderly and timely manner. Such failure may result from repeated tissue insults or underlying physiological conditions such as diabetes and malignancies, persistent infections, poor primary treatment, and other patient related

\footnotetext{
* Corresponding author.

E-mail address: lan11892@fct.unl.pt (LA. Neves).
}

factors, presenting a biological, psychological, social, and financial burden on both individual patients and, healthcare systems worldwide [3].

The development of advanced biomaterials for transdermal drug delivery is a growing area of biomedicine wherein intensive research is carried out, especially for chronic wound healing and/or efficient delivery of active pharmaceutical ingredients across skin. In fact, wound dressings are an important segment of the medical and pharmaceutical wound care market, with the Wound Dressing Market valued at USD 6309.62 billion in 2018 and expected to reach up to USD 11168.93 billion by 2025 with a Compound Annual Growth Rate (CAGR) of $8.50 \%$ over the forecast period, according to the Global Advanced Wound Dressing Market Report, by Brandessence Market Research and Consulting Pvt. ltd [4].

Considering a proper and timely wound healing, dressing selection should be mostly based on its ability to: i) provide or maintain moist environment; ii) enhance epidermal migration and promote angiogenesis, as well as connective tissue synthesis; iii) allow gas exchange between 
wounded tissue and the environment, towards maintenance of appropriate tissue temperature, in order to improve blood flow to the wound bed; iv) protect against bacterial infection; v) be non-adherent to the wound and easy to remove after healing; vi) provide debridement action to enhance leucocytes migration and support the accumulation of enzymes; and vii) be sterile, non-toxic and non-allergic [5].

Chitosan is one of the most studied biopolymers for wound dressings' application, mainly due to its biocompatibility and biodegradability, mostly arising from the presence of primary amines along the chitosan backbone [6]. Produced by chitin deacetylation, chitosan is a linear polysaccharide, composed of glucosamine and $\mathrm{N}$-acetyl glucosamine units linked by b (1-4) glycosidic bonds. Chitosan is an excellent candidate for wound dressing applications due to its non-toxicity, antimicrobial and anti-inflammatory properties, as well as its capacity to stimulate haemostasis and accelerate tissue regeneration [7-9]. Chitosan can be processed into different forms, such as hydrogels, scaffolds, sponges or films, and the latter are characterized by being thin, less obtrusive with the ability to act as a vehicle for transdermal drug delivery $[10,11]$.

Given their biological properties, safety and relatively low cost, bioactive plant extracts have been the subject of particular interest in the context of wound healing and transdermal drug delivery, namely as potential therapeutics for chronic wounds [12-15]. Comprising more than 5000 compounds, sesquiterpene lactones (SL) are one of the major groups of plant secondary metabolites presenting a high biological potential, namely anti-inflammatory [16-20]. Cynaropicrin, a guaianolide SL, has raised high scientific interest, due to biological activities such as regulation of major adhesion molecules CD29 and CD98 [21] and anti-inflammatory response [20]. Recently, Brás et al. described cynaropicrin extraction from Cynara cardunculus leaves and their optimization process using ethanol as solvent and pulsed ultrasound as assisted methodology (EtPUAE), followed by fractionation by membrane separation processes. [22-24].

To the best of our knowledge, this is the first report on the development and characterization of chitosan films doped with Cynara cardunculus leaves extracts, and evaluation of their potential use as wound dressing. In the present work, EtPUAE extracts from Cynara cardunculus leaves were incorporated into chitosan films, at different cynaropicrin/chitosan loadings $(1,5$ and $10 \%(w / w))$. The obtained films were characterized for their chemical and mechanical properties, as well as biological potential, with special focus on anti-cytotoxic and inflammatory activities.

\section{Materials and methods}

\subsection{Reagents and standards}

Chitosan $\geq 75 \%$ deacetylation degree was provided by Sigma Aldrich (USA). Acetic acid $>99.8 \%$, sodium chloride ( $>99.5 \%$ ) and potassium chloride (p.a.) were provided by Honeywell (USA), ethanol absolute $\geq 99.8 \%$ and potassium acetate were provided by BDh Prolabo (France), acetonitrile (HPLC grade) by Merck (France), and cynaropicrin was provided by Extrasynthese (France). Sodium bromide (99.0\%) was purchased from Alfa Aesar (USA) Dimethyl sulfoxide (DMSO) cell culture grade was obtained from Applichem (Germany). 3-(4,5-dimethylthiazol-2-yl)-2,5diphenyltetrazolium bromide (MTT) and propidium iodide was purchased from Calbiochem (USA). Acridine orange was purchased from Invitrogen (USA). DMEM, Medium 199, fetal bovine serum (FBS) suitable for cell culture, bovine serum albumin (BSA) (>96\% purity), Lipopolysaccharides from Escherichia coli 0111:B4 (LPS) and Piroxicam ( $\geq 98 \%)$ were purchased from Sigma Chemicals Co (Spain). Human IL-6 ELISA development kit (HRP) was purchased from Mabtech (Sweden).

\subsection{Raw material}

Cynara cardunculus L (DC) leaves were collected in June 2016 at the Experimental Center of Agriculture School of Instituto Politécnico de
Beja, Portugal and preserved at $-80{ }^{\circ} \mathrm{C}$. Before extraction, samples were freeze-dried in a freeze-drier (Scanvac coolsafe, Labogene, Denmark). Freeze-dried leaves, with moisture content below the detection limit of $1 \%$, were grounded using a domestic mixed grinder (Moulinex, France), in order to obtain a powder constituted by particles with a size lower than $500 \mu \mathrm{m}$. After gridding, the freeze-dried powder was stored under vacuum at room temperature.

\subsection{Cynaropicrin extraction}

Ultrasonic assisted extraction (UAE) experiments were performed using a $20 \mathrm{kHz}$ UAE device (Bandelin HD3200, Germany), equipped with a $13 \mathrm{~mm}$ diameter titanium alloy (Ti-AI6-V4, Bandelin, Germany). Extraction was performed as described by Brás et al. [23]. Briefly, pulsed UAE, with a duty cycle of $25 \%$, a solid/liquid $(\mathrm{S} / \mathrm{L})$ ratio of $1 / 27(\mathrm{~g} / \mathrm{mL})$, extraction temperature of $44^{\circ} \mathrm{C}$ and amplitude of $67 \%(54.3 \mu \mathrm{m})$ was performed during $30 \mathrm{~min}$. After extraction, the ethanolic extract (EtPUAE extract) was filtered using a glass filter funnel, with porosity G4 and a 10-16 $\mu \mathrm{m}$ maximum nominal pore size. The solvent was evaporated at low pressure on a rotary evaporator (Hei-VAP Advantage, Heidolph, Germany) and dried extract was storage at room temperature till usage.

EtPUAE cynaropicrin content was determined by HPLC. A Dionex Ultimate 3000 system (Thermo Scientific, USA) equipped with a Diode Array detector was used. A Kinetex F5 $2.6 \mu \mathrm{m}(4.6 \times 150 \mathrm{~mm})$ column (Phenomenex, USA) was employed at $30^{\circ} \mathrm{C}$, using as mobile phase a mixture of water and acetonitrile $(75: 25(\mathrm{v} / \mathrm{v}))$ with a flow rate of 0.5 $\mathrm{mL} / \mathrm{min}$. All samples were pre-filtered with $0.22 \mu \mathrm{m}$ pore size membrane filters (Pall, USA).

\subsection{Films development}

Chitosan films, neat or with incorporated EtPUAE extracts, were prepared by the solvent evaporation method and adapted from Ferreira et al. [25]. A chitosan solution was prepared by adding $2 \%(w / v)$ in acetic acid aqueous solution $1 \%(\mathrm{v} / \mathrm{v})$ with magnetic stirring at $200 \mathrm{rpm}$ until the chitosan powder was completely dissolved. The polymer solution was vacuum filtrated twice using Miracloth $₫$ (Merck Millipore) as filter.

Chitosan films doped with EtPUAE extracts were also prepared. For that, EtPUAE extracts on the proportion of 1,5 and $10 \%(w / w)$ (cynaropicrin/chitosan) were firstly dissolved in $10 \mathrm{~mL}$ of ethanol and then added to a $25 \mathrm{~mL}$ filtered Chitosan solution. Chitosan and Chitosan with EtPUAE forming solutions were centrifuged at $5000 \mathrm{rpm}$ for $15 \mathrm{~min}$ to remove possible air bubbles. The solutions were then casted on polypropylene petri dishes ( $90 \mathrm{~mm}$ diameter) and dried at $40{ }^{\circ} \mathrm{C}$ for $48 \mathrm{~h}$. Dried chitosan-based films were peeled off, weighted and equilibrated at $25^{\circ} \mathrm{C}$ with different relative humidity ambiences, to further understand the influence of water on the final properties of the films. Defined saturated salt solutions were prepared in four different desiccators by mixing inorganic salts with distilled water, in order to obtain a specific relative humidity $(\mathrm{RH})$ as described in Table 1.

\subsection{Characterization of chitosan-based films}

\subsubsection{Scanning electron microscopy (SEM)}

Surface and cross section images were used to detect morphology differences on chitosan films, with and without EtPUAE extracts. The

Table 1

Relative humidity of air in contact with specific saturated salts at $25^{\circ} \mathrm{C}[51]$.

\begin{tabular}{ll}
\hline Salt & Relative humidity $(\mathrm{RH}(\%))$ \\
\hline Potassium acetate & 22.6 \\
Sodium bromide & 57.7 \\
Sodium chloride & 75.3 \\
Potassium chloride & 84.3 \\
\hline
\end{tabular}


films surface and cross section images were obtained with different magnifications, respectively $1000 \times$ and $3000 \times$, using an analytical Scanning Electron Microscope Hitachi 5-2400 equipment (Hitachi Ltd., Japan), equipped with a field-emission electron source of $15 \mathrm{kV}$. Prior to observation, films were cut with liquid nitrogen, mounted on a metal scrub and coated with a thin layer film of gold-paladium.

\subsubsection{Fourier transform infrared spectroscopy (FT-IR) analysis}

For the analysis of possible interactions established between EtPUAE extract components and chitosan, FT-IR spectra analysis was performed. FT-IR spectra were acquired using a Perkin Elmer Spectrum spectrometer (C105146, Perkin Elmer, France) equipped with Spectrum software (Perkin Elmer, France). Spectra were collected in the range of $4000-400 \mathrm{~cm}^{-1}$ with 10 scans repetitions.

\subsubsection{Swelling degree}

In order to determine the swelling degree of the prepared films, samples were cut into $10 \times 10 \mathrm{~mm}$ pieces, and thickness $\left(\varepsilon_{0}\right)$ was measured using a micrometer caliper (Mitutoyo, USA) with an accuracy of $0.1 \mu \mathrm{m}$. Films were immersed on phosphate buffered saline (PBS) solution at pH 7.4 during $24 \mathrm{~h}$ at $37^{\circ} \mathrm{C}$ and, subsequently, the thickness $\left(\varepsilon_{1}\right)$ was measured [26]. The swelling volumetric degree (SW) was calculated using Eq. (1):

$\mathrm{SW}_{\text {volumetric }}=\left(\frac{\varepsilon_{1}-\varepsilon_{0}}{\varepsilon_{0}}\right)$

where $\mathrm{SW}_{\text {volumetric }}$ corresponds to volumetric swelling, $\varepsilon_{0}$ and $\varepsilon_{1}$ correspond to the initial and final film thickness, respectively.

\subsubsection{Thermal properties}

To evaluate the thermal stability of the films prepared, thermogravimetric analyses (TGA) were performed using a TGA Q50 analyzer (TA instruments, USA). The samples were heated at a constant rate of 10 $\mathrm{K}$. $\mathrm{min}^{-1}$, from room temperature up to $873 \mathrm{~K}$, under argon atmosphere. The Universal Analysis software was used to determine the onset ( $\left.\mathrm{T}_{\text {onset }}\right)$ and decomposition $\left(\mathrm{T}_{\text {dec }}\right)$ temperatures.

\subsubsection{Mechanical properties}

Puncture tests were carried out using a TA.XTplus texture analyzer (Stable Micro Systems, UK) equipped with a $2 \mathrm{~mm}$ diameter cylindrical stainless steel probe. Samples were punctured through a hole (diameter of $10 \mathrm{~mm}$ ), at a constant speed of $1 \mathrm{~mm} \cdot \mathrm{s}^{-1}$.

Puncture stress $(\sigma, \mathrm{Pa})$ was calculated according to the following equation:

$\sigma=\frac{F}{S_{c}}$

where $F$ is the maximum force exerted by the probe $(\mathrm{N})$ and $S_{\mathrm{c}}$ is the probe cross-sectional area $\left(\mathrm{m}^{2}\right)$. In order to normalize results without the influence of membrane thickness, the puncture stress values were calculated $\left(\sigma_{\mathrm{n}}, \mathrm{MPa} / \mathrm{mm}\right)$ as follows:

$\sigma_{n}=\frac{\sigma}{\varepsilon_{0}}$

\subsubsection{Biological assays}

2.5.6.1. Indirect cytotoxicity assays. Cytotoxicity assays were performed by an indirect method following the ISO 10993-5:2009 guidelines for biological evaluation of medical devices [27]. In order to collect film extract, pieces of $2 \mathrm{~cm}^{2}$ were maintained in $5 \mathrm{~mL}$ of culture medium under controlled temperature $\left(37^{\circ} \mathrm{C}\right)$ and constant stirring rate $(200$ $\mathrm{rpm}$ ) for $24 \mathrm{~h}$. Extracts were then removed and diluted as follows: $100 \%, 75 \%, 50 \%$ and $25 \%$ using cell culture medium, for immediate use.
Bj5-ta human skin fibroblasts (American Type Culture Collection (ATCC)) were seeded at a density of $1.25 \times 10^{5}$ cells/well on a 96-well tissue culture plate and incubated for $24 \mathrm{~h}$, at $37{ }^{\circ} \mathrm{C}$ in a humidified atmosphere with $5 \% \mathrm{CO}_{2}$ (Sanyo Electric $\mathrm{CO}$, Japan). After this time, the culture medium was removed and cells were exposed to film extracts. Life control corresponded to cells simply incubated with culture medium ( $100 \%$ of the total volume). After $6 \mathrm{~h}$ and $24 \mathrm{~h}$, cell metabolic assay was assessed by a MTT (3-(4,5-dimethylthiazol-2-yl)-2,5-diphenyltetrazolium bromide, a tetrazole) assay, where $10 \%$ of the MTT reagent $(0.5 \mathrm{mg} / \mathrm{mL})$ dissolved in medium was added to each well, and cells were incubated at $37^{\circ} \mathrm{C}$ for $2 \mathrm{~h}$. The MTT solution was carefully aspirated, and formazan crystals were dissolved with a DMSO/EtOH (1:1 $(\mathrm{v} / \mathrm{v}))$ mixture. Absorbance was measured on a microplate reader (SpectraMax Plus, Molecular Devices, USA) at $570 \mathrm{~nm}$. All the results were normalized relatively to life control, which was considered as $100 \%$ of viability. Triplicates were performed, in three independent experiments for each treatment, and the data were expressed as mean \pm standard deviation. The viability results obtained for each film extract, at 6 and $24 \mathrm{~h}$, were analyzed using the Prism version 6.00 for Windows (GraphPad Software, USA). Where differences did exist, the source of the differences at a $p<0.05$ of significance level was identified by all pairwise multiple comparison procedure. The Tukey's test was used for pairwise comparisons.

2.5.6.2. IL6 (interleukin 6)-mediated skin inflammation. To determine the anti-inflammatory potential of film extracts, Bj5-ta cells were seeded at a density of $1.8 \times 10^{5}$ cells/mL on a 12-well tissue culture plate for $24 \mathrm{~h}$ before the following procedure. Then, cells were stimulated with 5 $\mathrm{ng} / \mathrm{mL}$ lipopolysaccharides (LPS) for $8 \mathrm{~h}$. After stimulation, culture medium was removed and inflamed cells were exposed to film extracts at $100 \%$ dilution, as well as to two EtPUAE extracts with different concentration $(1 \mu \mathrm{g} / \mathrm{ml}$ and $10 \mu \mathrm{g} / \mathrm{mL})$ and two cynaropicrin solutions with different concentration $(0.5 \mu \mathrm{g} / \mathrm{mL}$ and $5 \mu \mathrm{g} / \mathrm{mL})$ for $16 \mathrm{~h}$ at $37^{\circ} \mathrm{C}$ in a humidified atmosphere with $5 \% \mathrm{CO}_{2}$. Piroxicam, a known antiinflammatory drug, at a concentration of $10 \mu \mathrm{g} / \mathrm{ml}$, was used as negative control. A human ELISA kit was used to detect the IL-6 levels in accordance with the product manual. Triplicates were performed, in three independent experiments for each treatment, and the data was expressed as mean \pm standard deviation. The IL- 6 results obtained for each film extract, after $8 \mathrm{~h}$ of stimulation with LPS and after $16 \mathrm{~h}$ exposure to film extracts were analyzed using the Prism version 6.00 for Windows (GraphPad Software, USA). Where differences did exist, the source of the differences at a $p<0.05$ of significance level was identified by all pairwise multiple comparison procedure. The Tukey's test was used for pairwise comparisons.

2.5.6.3. Acridine orange/propidium iodide staining assay. BJ5-ta cells were seeded at $1.8 \times 10^{5}$ cells $/ \mathrm{mL}$ on a 12 -well tissue culture plate and left to stabilize overnight. The next day, the same conditions as for IL-6 assays were replicated. After the respective incubations, cells were washed with PBS and incubated with a propidium iodide (PI) solution (50 $\mu \mathrm{g} / \mathrm{mL}$ in PBS) for $15 \mathrm{~min}$, after which were incubated with an acridine orange (AO) solution ( $50 \mu \mathrm{g} / \mathrm{mL}$ in PBS) for another $15 \mathrm{~min}$. In all incubation periods, cells were maintained in a humidified atmosphere at 37 ${ }^{\circ} \mathrm{C}, 5 \% \mathrm{CO}_{2}$, in the dark. Cells were then micrographed with an inverted fluorescent microscope (Olympus IX71), using FTIC and TRITC filters.

2.5.6.4. Wound healing - scratch assay. Bj5-ta cells were seeded on an Ibidi $\mu$-plate 24 well (lbidi GmbH, Germany) at a density of $2.5 \times 10^{5}$ cells $/ \mathrm{mL}$ for wound healing assay and according to Ibidi® instruction manual [28]. Cells were incubated in a humidified atmosphere at 37 ${ }^{\circ} \mathrm{C}, 5 \% \mathrm{CO}_{2}$ to allow cell adhesion and the formation of a confluent monolayer. Thereafter, Ibidi culture inserts were removed, and cell monolayers with a cell-free gap of $500 \mu \mathrm{m} \pm 100 \mu \mathrm{m}$ were gently washed with PBS, followed by addition of film extracts at a $100 \%$ dilution. Cells were then incubated for different time periods ( 0,7 and $24 \mathrm{~h})$. Cells 
incubated in culture medium, within the same time periods, served as control. For each incubation period, the plate was placed under a phase-contrast microscope (Motic, China) equipped with a camera (Motic 2500 , Motic, China) and images were acquired at $10 \times$ magnification with a computer-based microscopy imaging system (Motic Images Plus 2.0, Motic, China). Cell migration quantification was performed using Wound healing ACAS (Automated Cellular Analysis System) image analysis (Ibidi GmbH, Germany). For each image, the gap area was measured at certain time intervals and compared to the initial gap area at time $\mathrm{t}=0$. Wound closure (expressed as a percentage) was calculated from the following equation:

Woundclosure $(\%)=\frac{\left(W_{t 0}-W_{t i}\right)}{W_{t 0}} \times 100$

where, $W_{t o}$ and $W_{t i}$ correspond to the initial and time interval measured area, respectively.

\section{Results and discussion}

Relative humidity may influence chitosan film properties. Based on this, chitosan and chitosan enriched with 1, 5 and $10 \%$ EtPUAE, were exposed to different relative humidity values, until a constant mass was achieved. The films obtained were then characterized as described below.

\subsection{Scanning electron microscopy (SEM)}

Chitosan films obtained by solvent evaporation method were colorless, transparent and bright. Incorporation of EtPUAE extracts at different cynaropicrin/chitosan ratios $(1,5$ and $10 \%(w / w))$, led to greenish but shiny films, as can be observed in Fig. 1 (a1 to d1).

Surface and cross section images of films obtained by SEM, at the four water activities under study, did not present significant differences
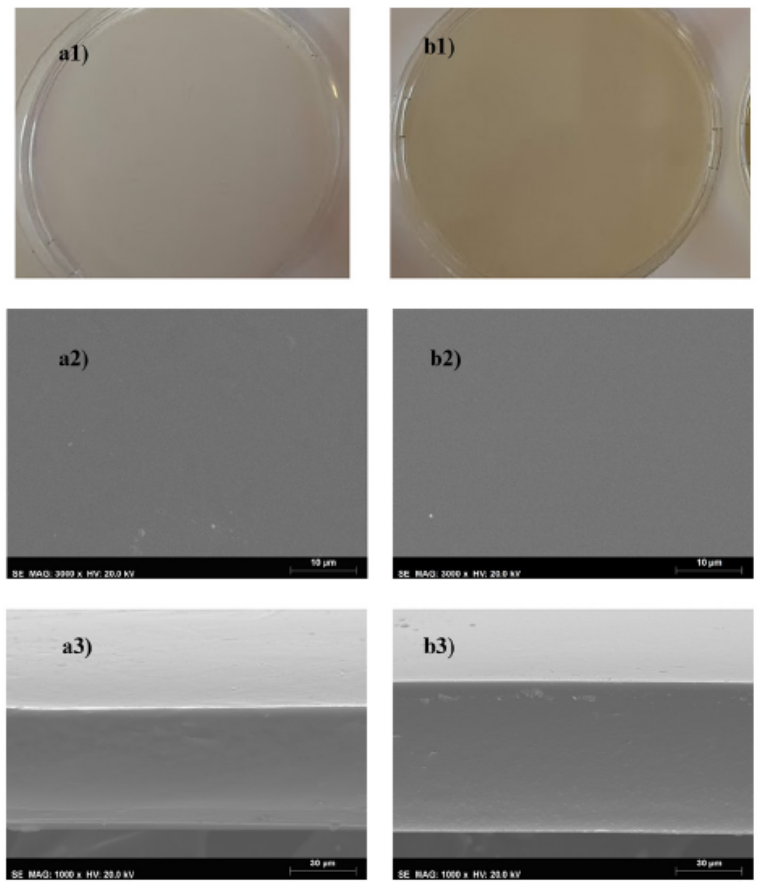

between them, therefore, only surface and cross section images for an RH of $57.7 \%$ are presented in Fig. 1.

From the surface images obtained, it is possible to observe that the films prepared are dense and homogeneous, without visible cracks or defects, and no differences detectable between the chitosan film (Figure a2), and chitosan incorporated with EtPUAE extracts (1, 5 and $10 \%(w / w)$ (Figures b2, c2 and d2, respectively). Regarding the crosssection images, the obtained results show that EtPUAE extracts are well dispersed in chitosan, presenting also a dense and a homogeneous structure (figures a3 to $\mathrm{d} 3$ ).

\subsection{FT-IR}

In order to understand the existence of possible molecular interactions between chitosan and EtPUAE extracts, a FT-IR analysis was performed to chitosan, chitosan $+1 \%$ EtPUAE, chitosan $+5 \%$ EtPUAE and chitosan $+10 \%$ EtPUAE films, at a RH of $22.6 \%, 57.7 \%, 75.3 \%$ and $83.3 \%$. The results obtained for films conditioned at a $\mathrm{RH}$ of $57.7 \%$ are depicted in Fig. 2. A similar pattern was observed for the four spectra obtained, although with some different transmittance intensities at certain peaks. Chitosan characteristic peaks corresponding to $\mathrm{OH}$-stretching $\left(3400-3300 \mathrm{~cm}^{-1}\right), \mathrm{N}-\mathrm{H}$ stretching in the amino group $(3500-3300$ $\left.\mathrm{cm}^{-1}\right), \mathrm{C}-\mathrm{H}$ symmetric and asymmetric stretching (3000-2850 $\left.\mathrm{cm}^{-1}\right), \mathrm{C}=\mathrm{O}$ stretching (amide I) $\left(1650 \mathrm{~cm}^{-1}\right), \mathrm{N}-\mathrm{H}$ bending (amide II) $\left(1539 \mathrm{~cm}^{-1}\right), \mathrm{C}-\mathrm{N}$ (amide III) $\left(1323 \mathrm{~cm}^{-1}\right)$, asymmetric stretching of the C-O-C bridge $\left(1153 \mathrm{~cm}^{-1}\right)$ and $\mathrm{C}-\mathrm{O}$ stretching (1024 and 1066 $\mathrm{cm}^{-1}$ ), were detected and are in accordance with previously reported results $[29,30]$.

The addition of EtPUAE extracts did not reveal significant wavelength shifts, which may indicate the inexistence of covalent bonds established between the extracts and chitosan [31]. A new peak at $1746 \mathrm{~cm}^{-1}$, characteristic of $\mathrm{C}=0$ stretching ( $\delta$-lactone) [32], was observed as well as an intensity increase with an increasing extract concentration in the chitosan films (Fig. 2b). This peak, also identified on
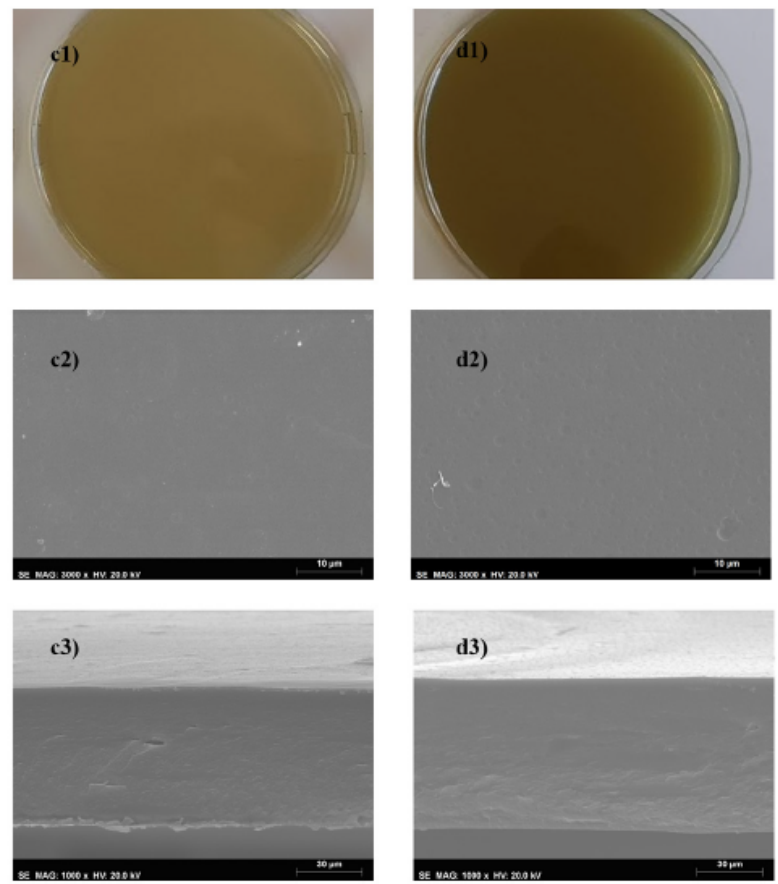

Fig. 1. Photographs of films of chitosan (a1); chitosan $+1 \%$ EtPUAE (b1); chitosan $+5 \%$ EtPUAE (c1); and chitosan $+10 \%$ EtPUAE (d1). SEM surface images of films (amplification $3000 x$ ) of chitosan (a2); chitosan $+1 \%$ EtPUAE (b2); chitosan $+5 \%$ EtPUAE (c2); and chitosan $+10 \%$ EtPUAE (d2). SEM cross-section images of films equilibrated at RH of $57.7 \%$ (amplification $1000 \times$ ) of chitosan (a3); chitosan +1\% EtPUAE (b3); chitosan +5\% EtPUAE (c3); and chitosan + 10\% EtPUAE (d3). 
a)

EtPUAE

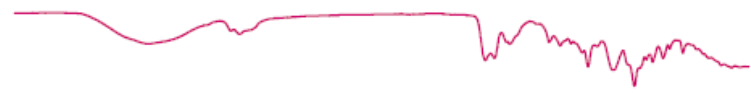

Chitosan $+10 \%$ EtPUAE

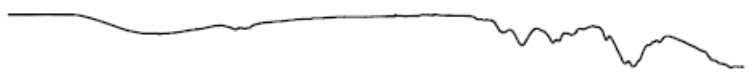

Chitosan $+5 \%$ EtPUAE

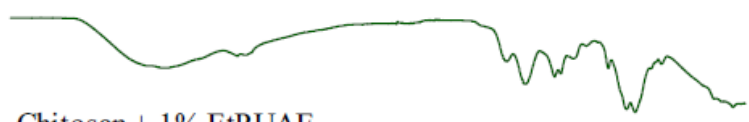

Chitosan $+1 \%$ EtPUAE
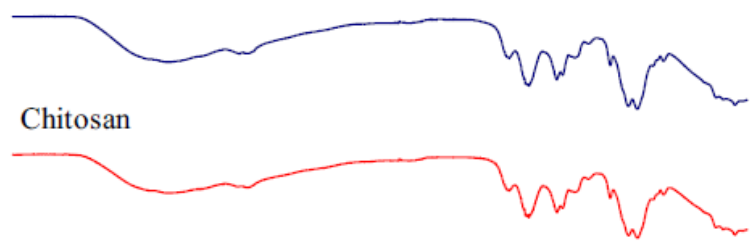

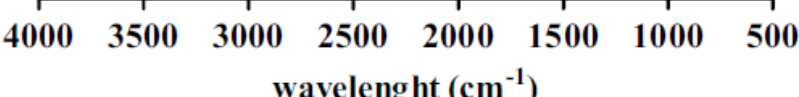

b)

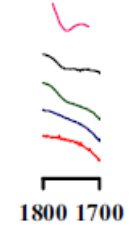

wave le nght $\left(\mathrm{cm}^{-1}\right)$

Fig. 2. FT-IR spectra for chitosan, chitosan $+1 \%$ EtPUAE, chitosan $+5 \%$ EtPUAE, chitosan $+10 \%$ EtPUAE and EtPUAE at a RH of $57.7 \%$ where a) corresponds to full spectra and b) corresponds to detailed spectra on the sesquiter pene lactone peak wavelength zone $\left(1700-1800 \mathrm{~cm}^{-1}\right)$.

a)<smiles>C=C(CO)C(=O)O[C@H]1CC(=C)[C@H]2C[C@H](O)C(=C)[C@@H]2[C@H]2OC(=O)C(=C)[C@H]12</smiles>

b)

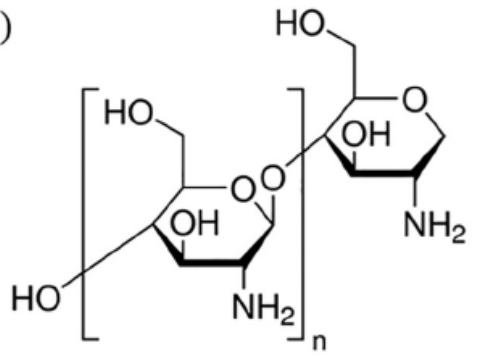

Fig. 3. Chemical structures of cynaropicrin a) and chitosan b).

the EtPUAE spectra could be attributed to cynaropicrin, a sesquiterpene lactone identified as the major compound found on EtPUAE extracts [23].

For the chitosan film prepared with $10 \%(\mathrm{w} / \mathrm{w})$ cynaropicrin, a decrease on the broad peak of -OH stretching (3400-3300 $\mathrm{cm}^{-1}$ ) and/or $-\mathrm{NH}\left(1539 \mathrm{~cm}^{-1}\right)$ was observed and this may be due to possible binding interactions between cynaropicrin - $\mathrm{OH}$ groups (Fig. 3a) and -OH or -NH chitosan groups Fig. 3b). Sun et al. [31] reported the same effect with hydrogen bonds established between polyphenols and chitosan, contributing to the interaction between these two compounds (Fig. 4).

When comparing the relative humidity effect on the chitosan film spectra it was possible to observe a decrease in characteristic peaks with reducing relative humidity. A low value for the $-\mathrm{OH}$ vibrational band can be attributed to a lower content of water molecules, whereas the increase of intensity from $57.7 \%$ to $84.3 \%$ of $\mathrm{RH}$ can be associated to increasing hydrogen bonding between chitosan chains, as explained by Sanchez el al 2017 [33].

When analyzing FT-IR spectra of chitosan $+10 \%$ EtPUAE at 22.6 and 75.3\% relative humidity and comparing it with neat chitosan FT-IR,
RH $84.3 \%$

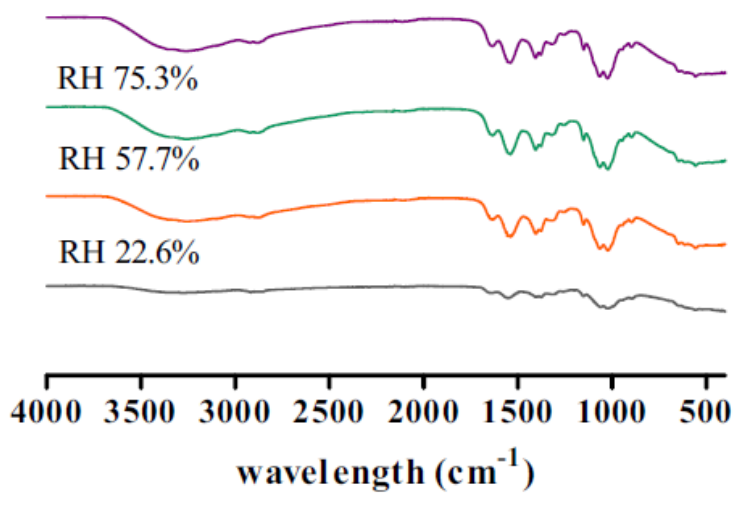

Fig. 4. FT-IR spectra for chitosan film conditioned at different relative humidity values: $22.6 \% ; 57.7 \% ; 75.3 \%$ and $84.3 \%$ 
a)

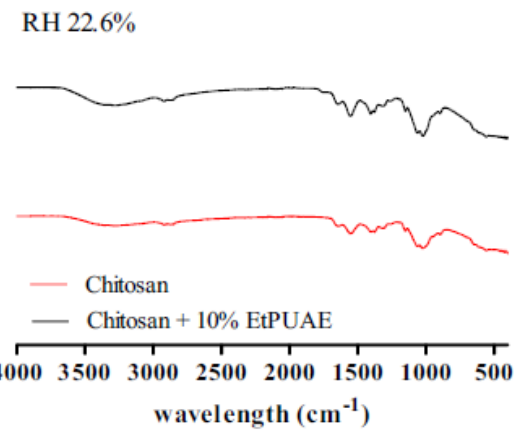

b)

RH $75.3 \%$
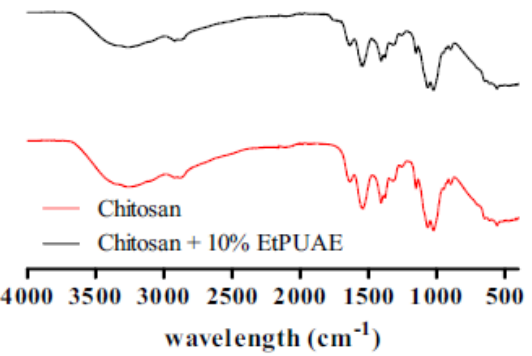

Fig. 5. FT-IR spectra of chitosan film and chitosan $+10 \%$ EtPUAE, conditioned at a) RH $22.6 \%$ and b) RH $75.3 \%$

respectively, Fig. 5a) and b), it is possible to observe that, at lower $\mathrm{RH}$, the film with the extract presents an - $\mathrm{OH}$ vibrational band more intense than the film without extract. The higher intensity observed for the chitosan $+10 \%$ EtPUAE film at low RH, comparatively to neat chitosan film, could be attributed to hydrogen bonding between extract and chitosan, which is in accordance to what was mentioned before. On the contrary, at higher RH, a similar effect cannot be observed because the higher water content overshadows the signal associated with hydrogen bonding.

\subsection{Swelling}

The creation of an optimal moist wound hea ling environment is critical to reduce the risk of complications on the surrounding skin and, based on this, wound dressings need to be able to absorb and retain exudates while maintaining an optimum level of moisture at the wound surface, which in turn must not spread to the surrounding skin [34]. Phosphate buffered saline (PBS) mimics, for in vitro assessment, the osmolarity and ion concentrations of the human body fluids. For this reason, PBS was selected for swelling experiments.

With respect to the swelling effect upon the different $w_{\mathrm{cyn}} / \mathbf{w}_{\text {chitosan }}$ ratios tested, it was possible to observe a general decrease of the film swelling capacity, with increasing EtPUAE extract concentration (Table 2). The presence of hydrophobic compounds (e.g. cynaropicrin) reduces polymer hydrophilicity, decreasing its affinity to PBS, leading to a lower swelling ability, as observed by several authors during the addition of lipidic fractions into chitosan films [30,35,36].

An increase of chitosan volumetric swelling was observed with an increase of the relative humidity, from $134 \%$ to $945 \%$ ( $p<0.05$ ) (Table 2).

As explained by some authors, a high relative humidity increases hydrophilic polymers moisture content, opening new binding sites for water, increasing its ability to PBS sorption, as observed for chitosan films [37]. The incorporation of EtPUAE, due to its hydrophobic character, reverses this increase, leading to the lowest volumetric swelling effect. Considering an optimum exudate control on wound site, higher
EtPUAE content should be considered for light exudate wounds. Nevertheless, all films presented higher swelling degree comparing to the commercially available dressing, Tegaderm ${ }^{\mathrm{TM}}$ (9\% after $\left.48 \mathrm{~h}\right)$ [38].

\subsection{Thermogravimetric analysis (TGA)}

Thermogravimetric results for films of chitosan and chitosan loaded with EtPUAE are represented in Fig. 6 . For the chitosan film, a first mass loss was observed between $307 \mathrm{~K}$ and $428 \mathrm{~K}$, corresponding to evaporation of water molecules present in the films [39]. Thermal decomposition of the chitosan film occurs between $400 \mathrm{~K}$ and $650 \mathrm{~K}$, due to denaturation of the chitosan polymeric structure, which is in accordance with the literature [39-41].

In Table 3 and Fig. 6, it is possible to observe that, although $\mathrm{T}_{\text {onset }}$ decreases with the increase of cynaropicrin concentration in films, such decrease is not significant, for the same relative humidity and for the different chitosan - based films under study. Exception made for the $\mathrm{RH}$ of $22.6 \%$ where a higher percentage weight loss was observed for the chitosan film, which could be attributed to the lower moisture content, as observed from the swelling results.

The results obtained show that the thermal stability of chitosan films is not affected by the incorporation of EtPUAE extracts and relative humidity. Considering the final application as wound dressing, the TGA analysis revealed that, at $37{ }^{\circ} \mathrm{C}$, no weight loss was observed for the chitosan-based films, supporting their suitability for skin wound application.

\subsection{Mechanical properties}

The values of tension under puncture are represented on Table 4. The results show that, for the same relative humidity, the incorporation of EtPUAE extracts promotes a decrease of the films tension upon rupture, although it is not observed a linear and statistically different decrease with the increase of the EtPUAE film content $(p<0.05)$. As stress represents the maximum strength that films can support before breaking, the results indicate that films produced with the EtPUAE

Table 2

Volumetric swelling values obtained after $24 \mathrm{~h}$ immersion in a PBS solution, for chitosan, chitosan $+1 \%$ EtPUAE, chitosan $+5 \%$ EtPUAE, chitosan $+10 \%$ EtPUAE, for films prepared under four different relative humidities of $22.6,57.7,75.3$ and $84.3 \%$.

\begin{tabular}{|c|c|c|c|c|}
\hline & Chitosan & Chitosan $+1 \%$ EtPUAE & Chitosan $+5 \%$ EtPUAE & Chitosan $+10 \%$ EtPUAE \\
\hline $\mathrm{RH}=22.6 \%$ & $134 \pm 5^{a}$ & $151 \pm 3^{a}$ & $103 \pm 3^{a}$ & $76 \pm 4^{a}$ \\
\hline $\mathrm{RH}=57.7 \%$ & $363 \pm 25^{b}$ & $115 \pm 9^{b}$ & $90 \pm 6^{\mathrm{b}}$ & $72 \pm 12^{\mathrm{a}}$ \\
\hline $\mathrm{RH}=75.3 \%$ & $453 \pm 31^{c}$ & $94 \pm 14^{b, c}$ & $62 \pm 9^{c}$ & $46 \pm 5^{b}$ \\
\hline $\mathrm{RH}=84.3 \%$ & $945 \pm 35^{d}$ & $77 \pm 8^{c}$ & $66 \pm 4^{c}$ & $45 \pm 6^{\mathrm{b}}$ \\
\hline
\end{tabular}

Average \pm standard deviation estimated from three extracts analyzed in triplicate. Values with different superscripts, within the same column, are statistically different ( $\mathrm{p}<0.05$ ). 
a)

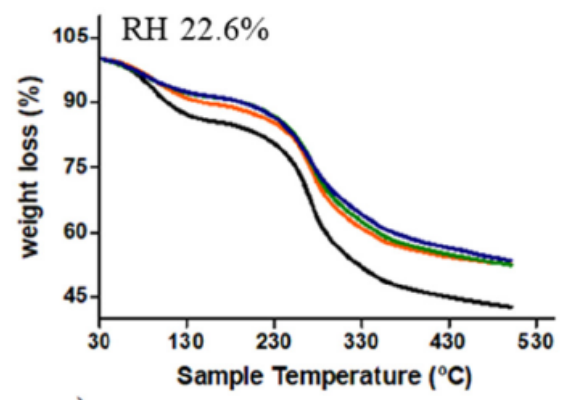

c)

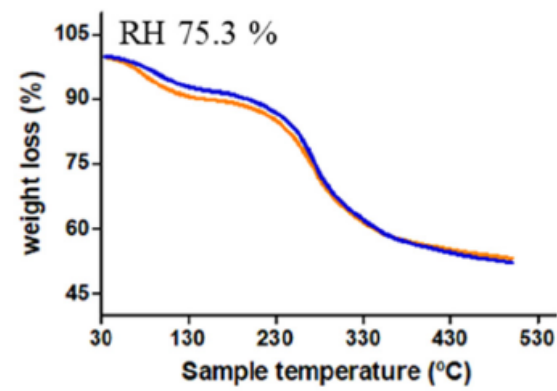

b)

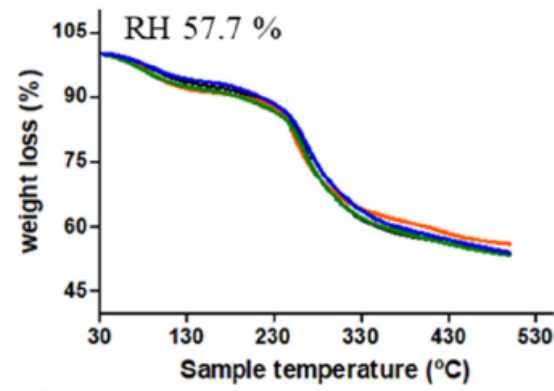

d)

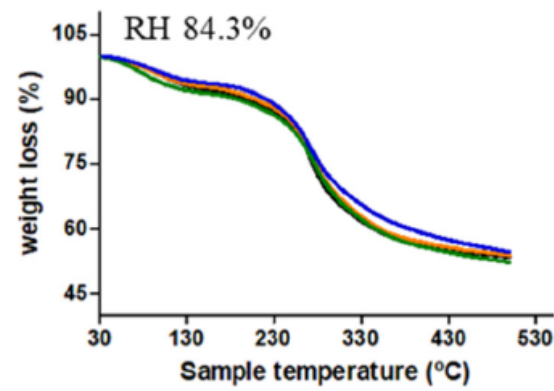

Fig. 6. TGA results expressed in terms of sample weight loss (\%) as a function of sample temperature $\left({ }^{\circ} \mathrm{C}\right.$ ) for chitosan (black), chitosan $+1 \%$ EtPUAE (red), chitosan $+5 \%$ EtPUAE (green) and chitosan + 10\% EtPUAE (blue), conditioned at a) RH $22.6 \%$, b) RH $57.7 \%$, c) RH $75.3 \%$, d) RH $84.3 \%$.

extract incorporation present a lower mechanical resistance when compared with that produced only with chitosan. A similar behavior was observed by other authors, when adding carvacrol, $\alpha$-tocopherol or apple polyphenols to a chitosan matrix [31,42,43]. It was proposed that the addition of hydrophobic compounds to the hydrophilic chitosan medium, induces the development of structural discontinuities in the highly packed chitosan matrix, lowering its ability to resist to mechanical solicitations [44]. The same behavior is envisaged to occur in the present work, considering the EtPUAE hydrophobic behavior and the molecular interactions between EtPUAE compounds and the chitosan polymer, which may weaken the polymer chain aggregation forces.
Furthermore, films with the same extract content show a substantial decrease of puncture stress with an increase of the relative humidity. The lowest value $\left(60.11 \pm 5.66{\left.\mathrm{MPa} . \mathrm{mm}^{-1}\right)}^{-1}\right.$ was observed for the highest relative humidity (84.3\%) and the highest EtPUAE content (10\%). This fact is attributed to the plasticizer effect of sorbed water that reduces polymer-polymer interactions, lowering the films mechanical strength. However, the lower tensile strength obtained, did not prevent their use on skin healing since that according to some authors, the tensile strength of human skin tissue, varies between 5 and $30 \mathrm{MPa}$ [45] although some authors have suggested that pre-stresses may be as great as $1 \mathrm{MPa}[46]$.

Table 3

Onset temperature (Tonset $(\mathrm{K})$ ) and decomposition temperature (Tdec $(\mathrm{K})$ ) for the different films under study, chitosan, chitosan $+1 \% \mathrm{EtPUAE}$, chitosan $+5 \% \mathrm{EtPUAE}$ and chitosan $+10 \%$ EtPUAE and for the relative humidity values tested: $22.6,57.7,75.3$ and $84.3 \%$.

\begin{tabular}{|c|c|c|c|c|c|c|c|c|}
\hline & \multicolumn{2}{|l|}{ Chitosan } & \multicolumn{2}{|c|}{ Chitosan $+1 \%$ EtPUAE } & \multicolumn{2}{|c|}{ Chitosan + 5\% EtPUAE } & \multicolumn{2}{|c|}{ Chitosan + 10\% EtPUAE } \\
\hline & $\mathrm{T}_{\text {onset }}(\mathrm{K})$ & $\mathrm{T}_{\mathrm{dec}}(\mathrm{K})$ & $\mathrm{T}_{\text {onset }}(\mathrm{K})$ & $\mathrm{T}_{\mathrm{dec}}(\mathrm{K})$ & $\mathrm{T}_{\text {onset }}(\mathrm{K})$ & $\mathrm{T}_{\mathrm{dec}}(\mathrm{K})$ & $\mathrm{T}_{\text {onset }}(\mathrm{K})$ & $\mathrm{T}_{\mathrm{dec}}(\mathrm{K})$ \\
\hline $\mathrm{RH}=22.6 \%$ & 431 & 538 & 428 & 522 & 426 & 532 & 421 & 542 \\
\hline $\mathrm{RH}=57.7 \%$ & 435 & 647 & 425 & 546 & 428 & 546 & 428 & 546 \\
\hline $\mathrm{RH}=75.3 \%$ & 426 & 546 & 419 & 546 & 422 & 546 & 421 & 544 \\
\hline $\mathrm{RH}=84.3 \%$ & 438 & 542 & 438 & 545 & 435 & 542 & 436 & 547 \\
\hline
\end{tabular}

Table 4

Tensile strength $(\mathrm{MPa} / \mathrm{mm})$ and elongation at break $(\%)$ for chitosan, chitosan $+1 \%$ EtPUAE, chitosan $+5 \%$ EtPUAE and chitosan $+10 \%$ EtPUAE for the relative humidity tested, $22.6,57.7$, 75.3 and $84.3 \%$

\begin{tabular}{lllll}
\hline RH $(\%)$ & Tension $(\mathrm{MPa} / \mathrm{mm})$ & & \\
\cline { 2 - 5 } & Chitosan & Chitosan $+1 \%$ EtPUAE & Chitosan $+5 \%$ EtPUAE & $124.8 \pm 0.44^{\mathrm{c}}$ \\
\hline 22.6 & $215.55 \pm 19.04^{\mathrm{a}}$ & $139.15 \pm 1.92^{\mathrm{b}}$ & $102.43 \pm 7.99^{\mathrm{b}}$ & $114.75 \pm 0.26^{\mathrm{d}}$ \\
57.7 & $137.90 \pm 0.83^{\mathrm{a}}$ & $111.61 \pm 4.03^{\mathrm{b}}$ & $79.91 \pm 5.48^{\mathrm{b}}$ & $106.85 \pm 2.25^{\mathrm{b}}$ \\
75.3 & $115.23 \pm 4.37^{\mathrm{a}}$ & $110.20 \pm 3.38^{\mathrm{a}}$ & $81.09 \pm 8.94^{\mathrm{a}}$ & $78.34 \pm 11.59^{\mathrm{b}}$ \\
84.3 & $88.59 \pm 1.05^{\mathrm{a}}$ & $83.74 \pm 0.55^{\mathrm{a}}$ & $60.11 \pm 5.66^{\mathrm{b}}$ & \\
\hline
\end{tabular}

Average \pm standard deviation estimated from three extracts analyzed in triplicate. Values with different superscripts, within the same column, are statistically different ( $p<0.05$ ) 
Table 5

Bj5-ta cell viability (\%) after 6 and $24 \mathrm{~h}$ of incubation for films of chitosan, chitosan $+1 \%$ EtPUAE, chitosan + $5 \%$ EtPUAE and chitosan + 10\% EtPUAE, as well as cynaropicrin concentration in each film extract. IC $\mathrm{C}_{50}(\mu \mathrm{g} / \mathrm{mL})$ for the Bj5-ta cell line, after 6 and $24 \mathrm{~h}$ of incubation, for EtPUAE and cynaropicrin.

\begin{tabular}{llll}
\hline \multirow{2}{*}{ Film } & \multicolumn{2}{l}{ Cell viability $(\%)$} & \multirow{2}{l}{$\begin{array}{l}\text { Cyn film extract } \\
(\mu \mathrm{g} / \mathrm{mL})\end{array}$} \\
\cline { 2 - 3 } & $6 \mathrm{~h}$ & $24 \mathrm{~h}$ & \\
\hline Chitosan & $98.4 \pm 4.6^{\mathrm{a}}$ & $95.8 \pm 7.1^{\mathrm{a}}$ & - \\
Chitosan +1\% EtPUAE & $95.7 \pm 5.0^{\mathrm{a}}$ & $88.5 \pm 8.9^{\mathrm{a}, \mathrm{b}}$ & 0.177 \\
Chitosan +5\% EtPUAE & $75.6 \pm 5.7^{\mathrm{b}}$ & $81.4 \pm 8.9^{\mathrm{b}}$ & 2.96 \\
Chitosan + 10\% EtPUAE & $51.1 \pm 5.0^{\mathrm{c}}$ & $34.1 \pm 2.7^{\mathrm{c}}$ & 17.73 \\
& $\mathrm{IC50}(\mu \mathrm{g} / \mathrm{mL})$ & & \\
EtPUAE & $36.1 \pm 1.6$ & $24.1 \pm 1.1$ & - \\
Cynaropicrin & $15.9 \pm 1.4$ & $9.7 \pm 1.0$ & - \\
\hline
\end{tabular}

Average \pm standard deviation estimated from three extracts analyzed in triplicate. Values with different superscripts, within the same column, are statistically different $(p<0.05)$.

\subsection{Biological activity}

\subsubsection{Cytotoxicity}

Biocompatibility, including low or absence of cytotoxicity are key factors for a material to be considered suitable for use as medical device. According to ISO 10993-5:2009 guidelines for biological evaluation of medical devices, a reduction on cell viability higher than $30 \%$ is considered to present a cytotoxic effect [27]. Indirect cytotoxicity assays for chitosan films, with extracts at different dilution rates, were performed with telomerase-immortalized human normal skin fibroblasts (Bj5-ta cell line) for incubation periods of 6 and $24 \mathrm{~h}$, as presented in Table 5 . According to the obtained results, after $6 \mathrm{~h}$ of exposure, the chitosan film led to a cell viability of $98.4 \pm 4.6 \%$, and the chitosan $+1 \%$ EtPUAE film resulted in a cell viability of $95.7 \pm 5.0 \%$, with no statistical difference between them $(\mathrm{p}<0.05)$. Although leading to a lower cell viability, according to the ISO 10993-5:2009 guidelines, the chitosan $+5 \%$ EtPUAE film $(75.51 \pm 5.67)$ was not considered cytotoxic. On the other hand, with a cell viability of $51.09 \pm 5.03 \%$, the chitosan $+10 \%$ EtPUAE film was considered cytotoxic. After $24 \mathrm{~h}$, no statistical difference was observed between the values for the non-cytotoxic films (neat chitosan and chitosan $+1 \%$ EtPUAE).

The $\mathrm{IC}_{50}$ values at 6 and $24 \mathrm{~h}$ for the EtPUAE extract and pure cynaropicrin was determined. In addition, cynaropicrin content in the film extracts used for the cytotoxicity experiments, was quantified. Analysis of the cynaropicrin content, shows that films with incorporation of 1 or $5 \%$ (w/w) EtPUAE extract contain respectively 0.177 and $2.96 \mu \mathrm{g} / \mathrm{mL}$ of cynaropicrin, a concentration below its $\mathrm{IC}_{50}(15.92 \pm$ $1.45 \mu \mathrm{g} / \mathrm{mL}$ ). Regarding the film of chitosan $+10 \%$ EtPUAE, at $6 \mathrm{~h}$ of incubation, a significant cell viability reduction was observed (51.09 \pm $5.03 \%)$. The final cynaropicrin concentration of film extract was 17.73 $\mu \mathrm{g} / \mathrm{mL}$ (chitosan $+10 \%$ EtPUAE film) indicating that the observed cytotoxicity is most probably directly correlated with the cynaropicrin concentration in the film.

\subsubsection{IL6 (interleukin 6)-mediated skin inflammation}

Continuous inflammation is a major cause of chronic wounds, and the expression modulation of pro-inflammatory interleukins is a suitable way to stop the inflammatory process, reducing epithelization, thus promoting a normal wound healing process [47]. IL-6 is one of the key pro-inflammatory factors produced by dermal fibroblasts in response to certain stimuli [48]. In this work, dermal fibroblasts (Bj5-ta) were stimulated with liposaccharide (LPS) and after this activation, which induces the IL-6 production, cells were exposed to the chitosan-based films under study. As controls, the EtPUAE extract and a cynaropicrin solution were directly applied to the stimulated Bj5-ta cells.

Interestingly, the IL-6 levels were reduced on stimulated Bj5-ta cells exposed to the film extracts (neat chitosan, chitosan+1\% EtPUAE and chitosan +5\% EtPUAE) (Fig. 7). A detailed analysis of results shows that, for the neat chitosan film, a reduction of IL-6 expression by LPSstimulated fibroblasts was achieved, without statistical difference, in comparison with $10 \mathrm{ng} / \mathrm{mL}$ piroxicam. Incorporation of EtPUAE into chitosan films seems to promote an anti-inflammatory effect as expressed by reduction of IL-6 levels, although without statistical difference comparing to neat chitosan $(\mathrm{p}>0.05)$. The strongest effect was observed for

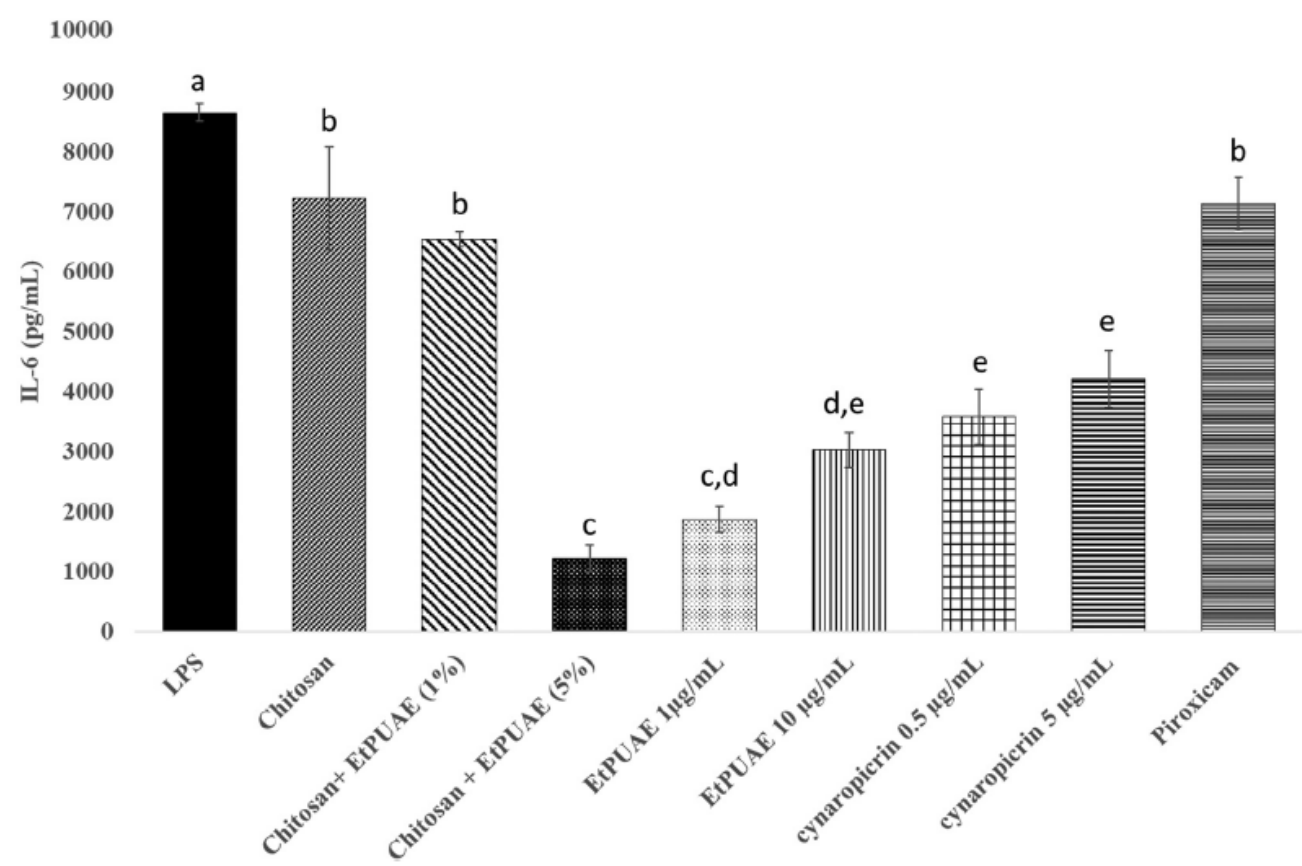

Fig. 7. ELISA quantification of IL- 6 produced by LPS-stimulated BJ-5ta cells after exposure to films of chitosan, chitosan $+1 \%$ EtPUAE, chitosan $+5 \%$ EtPUAE, and EtPUAE extracts at 1 and 10 $\mu \mathrm{g} / \mathrm{mL}$ and a solution of cynaropicrin at 0.5 and $5 \mu \mathrm{g} / \mathrm{mL}$. Piroxicam was used as a negative control at $10 \mathrm{ng} / \mathrm{mL}$ Levels of IL- 6 were measured after $8 \mathrm{~h}$ of incubation with the samples. 
Table 6

Cell viability for Bj5-ta LPS stimulated cells after $16 \mathrm{~h}$ of exposure to films of chitosan, chitosan + 1\% EtPUAE, chitosan +5\% EtPUAE and EtPUAE at 1 and $10 \mu \mathrm{g} / \mathrm{mL}$, calculated from $\mathrm{AO}+\mathrm{PI}$ assay

\begin{tabular}{ll}
\hline & Cell viability $(\%)$ \\
\hline Chitosan & $96.0 \pm 0.2$ \\
Chitosan $+1 \%$ EtPUAE & $95.0 \pm 2.0$ \\
Chitosan $+5 \%$ EtPUAE & $90.0 \pm 2.2$ \\
EtPUAE $1 \mu \mathrm{g} / \mathrm{mL}$ & $96.0 \pm 0.7$ \\
EtPUAE $10 \mu \mathrm{g} / \mathrm{mL}$ & $90.0 \pm 4.0$ \\
LPS & $95.0 \pm 1.3$ \\
Piroxicam & $79.0 \pm 4.1$ \\
\hline
\end{tabular}

the chitosan $+5 \%$ EtPUAE film, with a reduction of $\approx 86 \%$ and $83 \%$ in the IL-6 expression by skin fibroblasts, comparatively to LPS and the neat chitosan film $(\mathrm{p}<0.05)$, which is extremely promising for regulation of continuous inflammation in chronic wounds.

Further, the effect of the EtPUAE extract and the cynaropicrin solution was also evaluated, taking into account the cynaropicrin levels quantified in chitosan-based films (Table 5). With a cynaropicrin content of 51.7 $\mathrm{mg} / \mathrm{g}$ extract, a higher reduction of IL-6 levels was observed with the EtPUAE extract, when compared to the pure cynaropicrin solution (in the same concentration range). Although also effective, the EtPUAE extract at $10 \mu \mathrm{g} / \mathrm{mL}$ has a lower capacity to reduce IL-6 levels in stimulated cells when compared to the EtPUAE $1 \mu \mathrm{g} / \mathrm{mL}(\mathrm{p}<0.05)$, which may be related to a slight increase in the material's toxicity with the higher extract load. Although EtPUAE, as well as cynaropicrin, can reduce IL-6 levels according to the results presented in Fig. 7, there are no differences in regard to this cytokine quantification for cells incubated with EtPUAE extract $(10 \mu \mathrm{g} / \mathrm{mL})$ or cynaropicrin $(0.5$ and $5 \mu \mathrm{g} / \mathrm{mL}, 1.44$ and $14.4 \mu \mathrm{M}$, respectively) ( $\mathrm{p}>0.05$ ). These results support a more potent anti-inflammatory effect for the EtPUAE extract, comparatively to cynaropicrin, underlying an interesting synergetic effect for the extract.

Taking into account the cytotoxicity associated to cynaropicrin at 5 $\mu \mathrm{g} / \mathrm{mL}(14.4 \mu \mathrm{M})$ (Table 5), a dual staining with acridine orange (AO) and propidium iodide (PI) was performed to distinguish viable cells from apoptotic/necrotic cells. Vanden Berghe et al. [52] observed that necrosis is induced by several stimuli, such as tumor necrosis factor (TNF), anti-Fas (an apoptotic mediator) or double-stranded RNA, promote the secretion of the pro-inflammatory cytokine IL-6. According to our results, Table 6 and Fig. 8, the EtPUAE extract at $10 \mu \mathrm{g} / \mathrm{mL}$, and the cynaropicrin solution at $5 \mu \mathrm{g} / \mathrm{mL}$, induce a slight increase in cell death, as more PI (red) fluorescence is visible, comparatively to the lower tested concentrations. This could be related to necrosis promoted by high levels of the EtPUAE extract and cynaropicrin, mediated by increased levels of IL-6, as described by Vander Berghe et al. a)
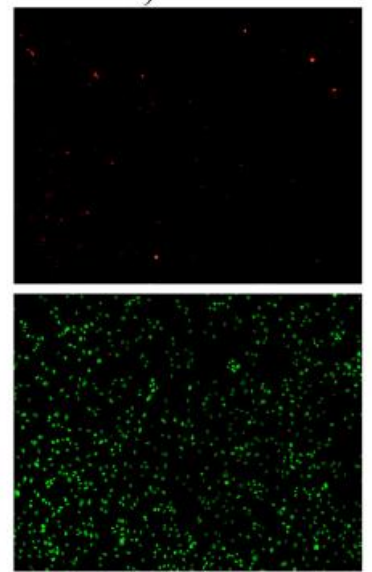

e)
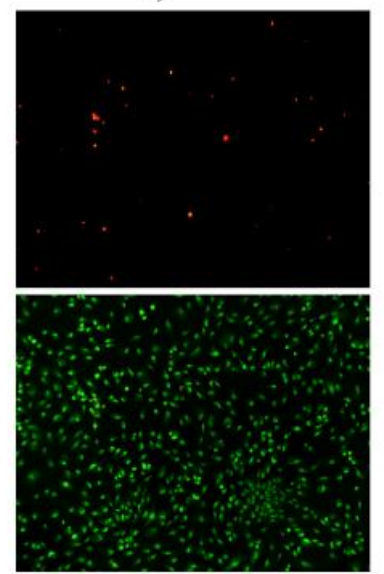

b)
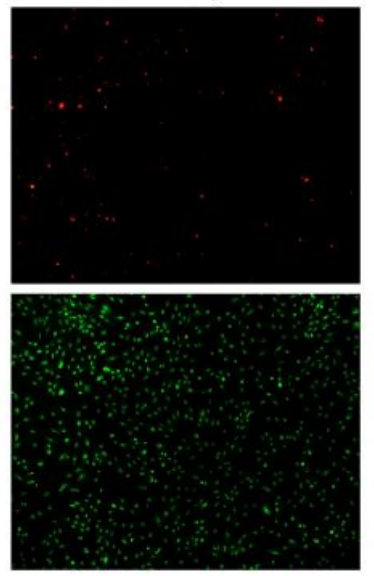

f)
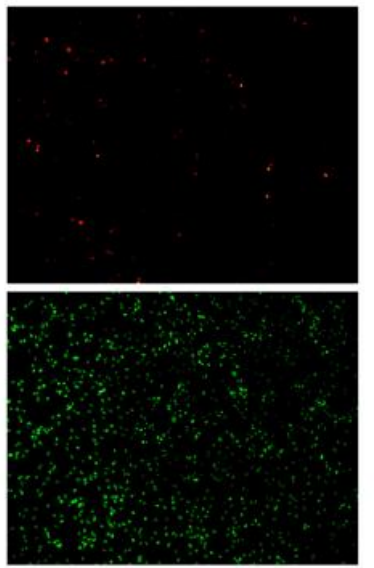

c)
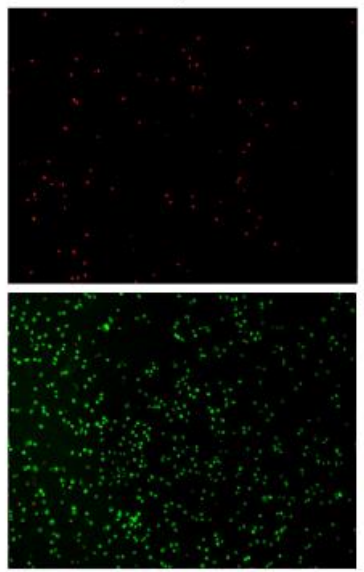

g)
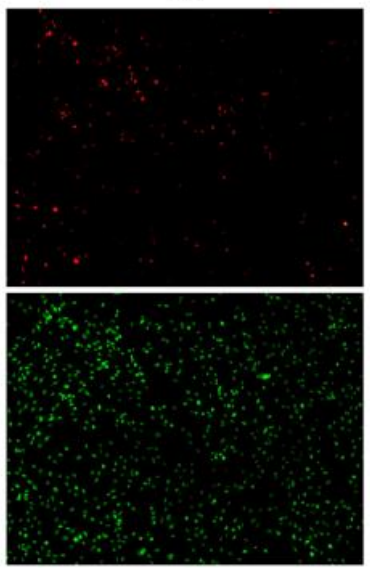

d)
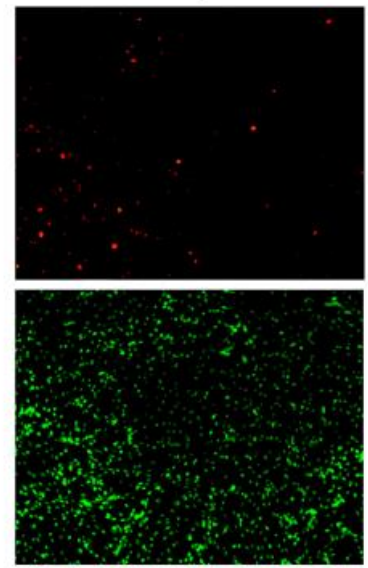

h)
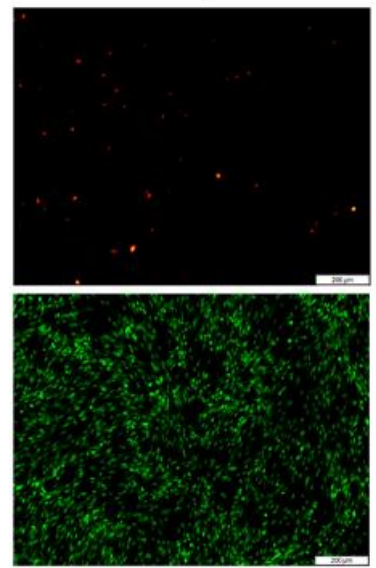

Fig. 8. Acridine orange (AO, green) and propidium iodide (PI, red) double staining fluorescent micrographs of LPS stimulated Bj5-ta cells after $16 \mathrm{~h}$ of exposure to: (a) chitosan film, (b) chitosan $+1 \%$ EtPUAE film, (c) chitosan $+5 \%$ EtPUAE film, (d.) EtPUAE $1 \mu \mathrm{g} / \mathrm{mL}$, (e) EtPUAE $10 \mu \mathrm{g} / \mathrm{mL}$ (f) positive control (LPS) (g) negative control (piroxicam) (h) unstimulated cells (life control). The images were captured in multiple times with a x 20 magnification. 
Table 7

Bj5-ta fibroblast wound closure rate after $7 \mathrm{~h}$ and $24 \mathrm{~h}$ of incubation with films of chitosan and chitosan +1\% EtPUAE

\begin{tabular}{lll}
\hline & $7 \mathrm{~h}$ & $24 \mathrm{~h}$ \\
\hline Control & $87 \pm 3 \%^{\mathrm{a}}$ & $22 \pm 6 \%^{\mathrm{a}}$ \\
Chitosan & $83 \pm 9 \%^{\mathrm{a}}$ & $28 \pm 8 \%^{\mathrm{a}}$ \\
Chitosan + 1\% EtPUAE & $84 \pm 6 \%^{\mathrm{a}}$ & $15 \pm 9 \%^{\mathrm{b}}$ \\
\hline
\end{tabular}

Average \pm standard deviation estimated from three extracts analyzed in triplicate. Values with different superscipts, within the same column, are statistically different $(\mathrm{p}<0.05)$.

Regarding the chitosan-based films, a very marginal reduction in the number of viable cells (green fluorescence) was observed for the chitosan $+5 \%$ EtPUAE film, which may also be related to extract-related toxicity.

Although this is the first time that cynaropicrin and EtPUAE extracts are tested in LPS-stimulated Bj5-ta fibroblasts, cynaropicrin's antiinflammatory potential has been previously monitored by IL-6 expression downregulation, in human keratinocytes. According to Takei et al., cynaropicrin at $1 \mu \mathrm{M}$ appeared to inhibit IL-6 and TNF- $\alpha$ upregulation in UVB-treated normal human epidermal keratinocytes [49]. The results presented here show that EtPUAE extracts and loaded chitosan films reveal a similar IL-6-mediated anti-inflammatory activity in skin fibroblasts, which supports their applicability for chronic wound management.

\subsubsection{Scratch assay}

Although a stronger reduction in IL-6 levels of LPS-stimulated fibroblasts was observed for the film of chitosan $+5 \%$ EtPUAE, a decrease in cell viability was also evident, which indicates a potential toxicity issue.
Therefore, wound healing assays were only performed for films of chitosan and of chitosan $+1 \%$ EtPUAE.

Fibroblasts are responsible for most collagen and elastin synthesis as well as organization of the extracellular matrix (ECM) components [50]. Therefore, normal skin fibroblasts were selected for this study due to their need for determination of wound closure. Analysis of results reported on Table 7 and Fig. 9, shows that, after $7 \mathrm{~h}$ of incubation, films with extract did not affect fibroblasts migration with statistical significance ( $p>0.05)$, comparatively to the sample control. On the other hand, after $24 \mathrm{~h}$ of incubation, a more effective wound closure was observed for the film with $1 \%$ EtPUAE $(p<0.05)$, which suggests that a concentration of $0.177 \mu \mathrm{g} / \mathrm{mL}$ cynaropicrin can promote a faster wound healing.

\section{Conclusions}

In this work chitosan and chitosan films loaded with different EtPUAE extracts were prepared, conditioned at different relative humidity values and characterized in terms of structure, swelling, thermal and mechanical properties. In addition, preliminary assessment of the biological properties (cytotoxicity, IL-6 mediated skin inflammation and wound healing) were performed in order to evaluate the prospective use of the films developed as wound dressing materials.

SEM analysis of chitosan and chitosan-based films produced, revealed a homogeneous and dense structure, although after EtPUAE loading, to the naked eye, green and shiny films were obtained, in opposition to clear and translucent neat chitosan films. A decrease of the volumetric swelling capacity was observed with the EtPUAE loading attributed to the extract hydrophobic character, which could be advantageous for wound dressings where an excessive fluid sorption is not 0h
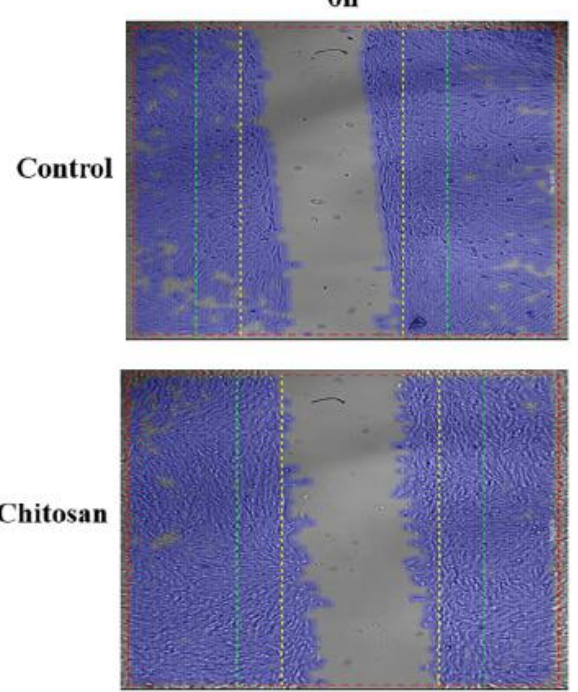

Chitosan

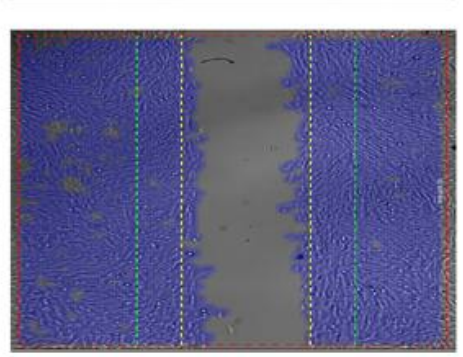

$7 \mathrm{~h}$
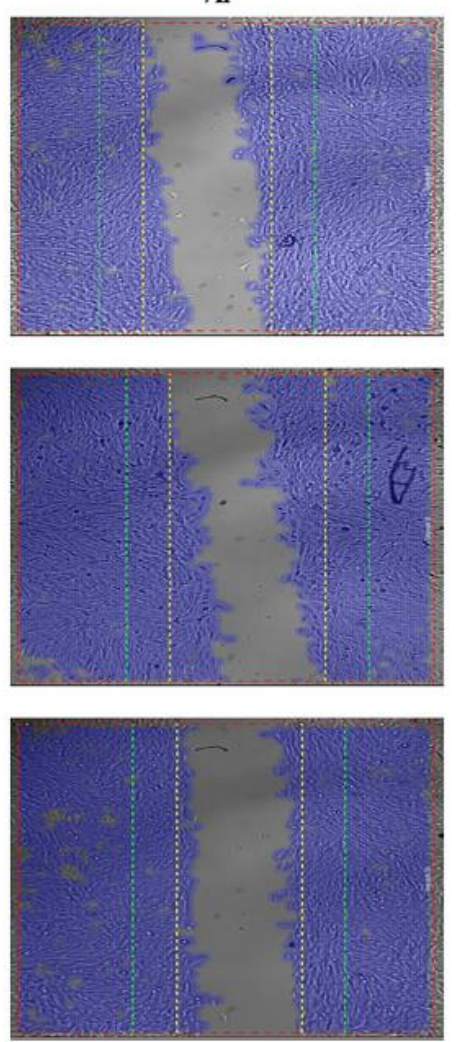

24h
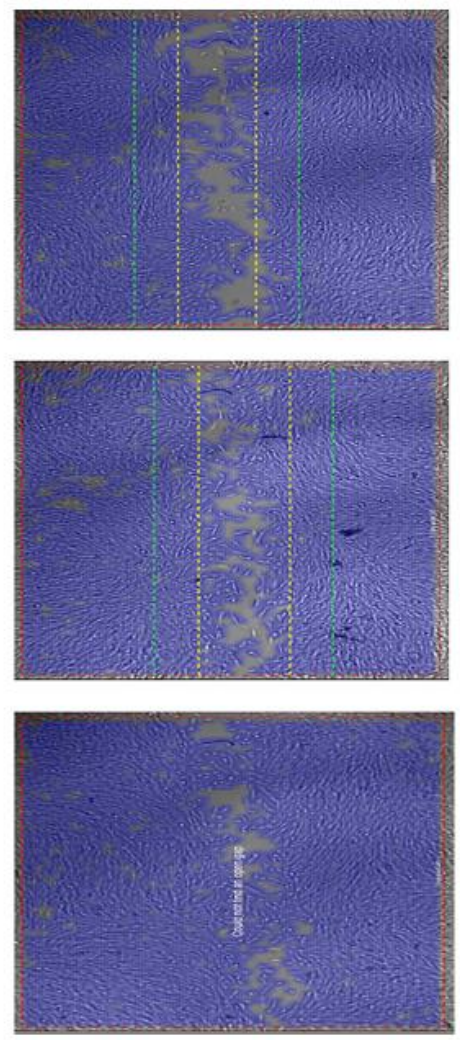

Fig. 9. Microscopical images representing the invitro scratch assay of chitosan based films: Bj5-ta cellswere incubated in the presence and absence of chitosan based films and images were captured at $7 \mathrm{~h}$ and $24 \mathrm{~h}$. The boundaries of the scratched wounds were determined by the yellow lines. 
desired. A decrease of the swelling effect was observed with the increase of relative humidity for neat the chitosan film, with the reverse effect observed for chitosan + EtPUAE films.

Chitosan-based FT-IR analysis did not reveal the presence of new covalent bonds established between chitosan and the incorporated extract, although an increase of - $\mathrm{OH}$ bands intensity was observed, which seems to indicate the presence of hydrogen bonding between EtPUAE and chitosan. Although no effects were apparent on the chitosan thermal stability, a decrease of the tensile strength with EtPUAE loading was observed. However, an increase of the tensile stress was obtained with the increase of relative humidity, attributed to a water plasticizer effect, with values obtained in accordance with skin tensile strength.

Biological studies show that, after $24 \mathrm{~h}$ of exposure, leading to a cell viability of $34.1 \pm 2.7 \%$ of Bj5-ta fibroblasts, the film of chitosan $+10 \%$ EtPUAE was considered to be cytotoxic, which was related with its cynaropicrin content. On the analysis of their anti-inflammatory activity, regarding the regulation of IL-6 levels on LPS-stimulated skin fibroblasts, both films of chitosan and chitosan $+1 \%$ EtPUAE show the same effect as the one obtained with piroxicam, with no statistical difference being observed. Nevertheless, the film of chitosan $+5 \%$ EtPUAE led to a significant reduction in the IL-6 levels comparatively to the LPS stimulated cells and with no treatment, lower than what is achieved with the commercial anti-inflammatory compound (at $10 \mathrm{ng} / \mathrm{mL}$ ), indicating its potential for chronic wound management. Besides that, a higher closure rate was achieved with the film of chitosan $+1 \%$ EtPUAE when compared to either the chitosan film, and the control.

Produced with naturally sourced materials, such as chitosan and Cynara cardunculus leaves this work opens up new perspectives for the use of chitosan films doped with EtPUAE extracts from Cynara cardunculus leaves for wound dressing materials, specifically for chronic wounds trapped in continuous inflammation.

\section{CRediT authorship contribution statement}

Teresa Brás: Conceptualization, Methodology, Validation, Formal analysis, Writing - original draft. Daniela Rosa: Methodology. Ana C. Gonçalves: Methodology. Andreia C. Gomes: Methodology, Validation. Vítor D. Alves: Methodology, Validation. João G. Crespo: Conceptualization, Supervision, Funding acquisition, Writing - review \& editing. Maria F. Duarte: Conceptualization, Supervision, Funding acquisition, Writing - review \& editing. Luísa A. Neves: Conceptualization, Supervision, Funding acquisition, Writing - review \& editing.

\section{Acknowledgements}

The authors want to thank to Regional Development European Foundation and Alentejo Region Operational Program (ALENTEJO 2020) for their financial support to "MedCynaraBioTec - Selection of Cynara cardunculus genotypes for new biotechnological applications: the value chain improvement of cardoon, a well-adapted Mediterranean crop Project (ALT20-03-0145-FEDER-039495). The authors acknowledge Fundação para a Ciência e a Tecnologia for the PhD grants to Teresa Brás (SFRH/BD/110969/2015) and Daniela Rosa (SFRH/BD/ $143845 / 2019)$, for the exploratory project (IF/00505/2014/CP1224/ CT0004) attributed to Luísa Neves within the 2014 FCT Investigator Programme and for financial support to "Tailor-made skin drug delivery biomaterials using new ionic liquids" (PTDC/CTM-CTM/29869/2017). This work was supported by the Associate Laboratory for Green Chemistry - LAQV which is financed by national funds from FCT/MCTES (UIDB/50006/2020). This work was also funded through FCT under the Project UIDB/05183/2020, UID/BIA/04050/2019 and UID/AGR/ 04129/2020 to Mediterranean Institute for Agriculture Environment and Development (MED), CBMA's strategic program and LEAF, respectively.

\section{References}

[1] N. Mayet, Y.E. Choonara, P. Kumar, L.K. Tomar, C. Tyagi, LC. Du Toit, V. Pillay, A comprehensive review of advanced biopolymeric wound healing systems, J. Pharm. Sci 103 (8) (2014) 221 1-2230, https://doi.org/10.1002/jps.24068.

[2] H. Sinno, S. Prakash, Complements and the wound healing cascade: an updated review, Plast. Surg. Int. 2013 (2013)https://doi.org/10.1 155/2013/146764.

[3] K. Järbrink, G. Ni, H. Sönnergren, A. Schmidtchen, C. Pang, R. Bajpai, J. Car, The humanistic and economic burden of chronic wounds: a protocol for a systematic review, Syst. Rev. 6 (1) (2017) 15, https://doi.org/10.1186/s13643-016-0400-8.

[4] O. Spring. J. Kupka, B. Maier, A. Hager, Biological activities of sesquiterpene lactones from Helianthus annuus: antimicrobial and cytotoxic properties; influence on DNA, RNA, and protein synthesis, Zeitschrift für Naturforschung C (1982) 1087.

[5] S. Dhivya, V.V. Padma, E. Santhini, Wound dressings - a review, BioMedicine 5 (4) (2015) 22, https://doi.org/10.7603/s40681-015-0022-9.

[6] S. Ahmed, S. Ikram, Chitosan based scaffolds and their applications in wound healing, Achiev. Life Sci. 10 (1) (2016) 27-37, https://doi.org/10.1016/j.als.2016. 04.001.

[7] T. Dai, M. Tanaka, Y.-Y. Huang, M.R Hamblin, Chitosan preparations for wounds and burns: antimicrobial and wound-healing effects, Expert Rev. Anti-Infect. Ther. 9 (7) (2011) 857-879, https://doi.org/10.1586/eri.11.59.

[8] H. Liu, C. Wang, C. Li, Y. Qin, Z. Wang, F. Yang, Z. Li, J. Wang, A functional chitosanbased hydrogel as a wound dressing and drug delivery system in the treatment of wound healing, R. Soc. Chem. Adv. 8 (14) (2018) 7533-7549, https://doi.org/10. $1039 / \mathrm{c} 7 \mathrm{ra} 13510 \mathrm{f}$

[9] A. Moeini, P. Pedram, P. Makvandi, M. Malinconico, G. Gomez d'Ayala, Wound healing and antimicrobial effect of active secondary metabolites in chitosan-based wound dressings: a review, Carbohydr. Polym. 233 (2020), 115839, https://doi. org/10.1016/j.carbpol 2020.115839.

[10] V. Patrulea, V. Ostafe, G. Borchard, O. Jordan, Chitosan as a starting material for wound healing applications, Eur. J. Pharm. Biopharm. 97 (2015) 417-426, https:// doi.org/10.1016/j.ejpb 2015.08.004.

[11] R. Jayakumar, M. Prabaharan, P.T. Sudheesh Kumar, S.V. Nair, H. Tamura, Biomaterials based on chitin and chitosan in wound dressing applications, Biotechnol. Adv. 29 (3) (2011) 322-337, https://doi.org/10.1016/j.biotechadv.2011.01.005.

[12] G. Schoukens, 5 - bioactive dressings to promote wound healing, in: S. Rajendran (Ed.), Advanced Textiles for Wound Care, Woodhead Publishing 2009, pp. 114-152, (978-1-84569-271-1).

[13] A.A. Muhammad, N.A.S. Pauzi, P. Arulselvan, F. Abas, S. Fakurazi, In vitro wound healing potential and identification of bioactive compounds from Moringa oleifera Lam, Biomed. Res. Int. 2013 (2013), 974580, https://doi.org/10.1155/2013/974580.

[14] S. Ghuman, B. Ncube, J.F. Finnie, LJ. McGaw, E. Mfotie Njoya, R.M. Coopoosamy, J. Van Staden, Antioxidant, anti-inflammatory and wound healing properties of medicinal plant extracts used to treat wounds and dermatological disorders, S. Afr. J Bot. 126 (2019) 232-240, https://doi.org/10.1016/jsajb 2019.07.013.

[15] B.P. George, T. Parimelazhagan, R Chandran, Anti-inflammatory and wound healing properties of Rubus fairholmianus Gard. root-an in vivo study, Ind. Crop. Prod. 54 (2014) 216-225, https://doi.org/10.1016/j.indcrop.2014.01.037.

[16] X. Jiang, Y. Chen, D. Liu, T. Shi, X. Cheng, W. He, Y. Li, B. Ryffel, S.G. Zheng, Y. Zheng. Secoeudesma sesquiterpenes lactone A alleviates inflammation and offers adjuvant protection in severe infection of carbapenem-resistant Klebsiella pneumoniae, J. Ethnopharmacol. 252 (2020), 112605, https://doi.org/10.1016/j.jep2020.112605.

[17] Z.-I. Wu, J.-x. Wang, L.-p. Chen, H.-y. Dong, H.-L. Li, W.-d. Zhang, Five rare C32 sesquiterpene lactone dimers with anti-inflammation activity from Vladimiria souliei, Fitoterapia 125 (2018) 117-122, https://doi.org/10.1016/jitote.2018.01.002

[18] R. Sabel, A.S. Fronza, L.Z.B. Carrenho, A. Maes, M.L. Barros, LA.E. Pollo, M.W. Biavatti, K. D'Herde, P. Vandenabeele, M.R.O. Kreuger, Anti-inflammatory activity of the sesquiterpene lactone diacethylpiptocarphol in dextransulfate sodium-induced colitis in mice, J. Ethnopharmacol. 245 (2019), 112186, https://doi.org/10.1016/j.jep. 2019.112186.

[19] M.C. Recio, RM. Giner, L. Uriburu, S. Máñez, M. Cerdá, J.R. De La Fuente, J.L Ríos, In vivo activity of pseudoguaianolide sesquiterpene lactones in acute and chronic inflammation, Life Sci. 66 (26) (2000) 2509-2518, https://doi.org/10.1016/S00243205(00)00585-3.

[20] J.Y. Cho, K.U. Baik, J.H. Jung, M.H. Park, In vitro anti-inflammatory effects of cynaropicrin, a sesquiterpene lactone, from Saussurea lappa, Eur. J. Pharmacol. 398 (3) (2000) 399-407, https://doi.org/10.1016/S0014-2999(00)00337-X.

[21] J.Y. Cho, A.R. Kim, H.-G. Joo, B.-h. Kim, M.H. Rhee, E.S. Yoo, D.R. Katz, B.M. Chain, J.H. Jung, Cynaropicrin, a sesquiterpene lactone, as a new strong regulator of $\mathrm{CD} 29$ and CD98 functions, Biochem. Biophys. Res. Commun. 313 (4) (2004) 954-961, https:// doi.org/10.1016/j.bbrc.2003.12.026

[22] T. Brás, L.A. Neves, J.G. Crespo, M.F. Duarte, Effect of extraction methodologies and solvent selection upon cynaropicrin extraction from Cynara cardunculus leaves, Sep. Purif. Technol. 236 (2020), 116283, https://doi.org/10.1016/j.seppur.2019. 116283.

[23] T. Brás, A.F.C. Paulino, L.A. Neves, J.G. Crespo, M.F. Duarte, Ultrasound assisted extraction of cynaropicrin from Cynara cardunculus leaves: optimization using the response surface methodology and the effect of pulse mode, Ind. Crop. Prod. 150 (2020), 112395, https://doi.org/10.1016/jind 0 op 2020.112395.

[24] T. Brás, D. Rosa, A.C. Gonçalves, A.C. Gomes, C. Brazinha, LA. Neves, M.F. Duarte, J.G. Crespo, Fractionation of Cynara cardunculus ethanolic extracts using diananofiltration, Separation and Purification Technology, 2020, (submitted).

[25] A.R.V. Ferreira, C.A.V. Torres, F. Freitas, C. Sevrin, C. Grandfils, M.A.M. Reis, V.D. Alves, I.M. Coelhoso, Development and characterization of bilayer films of FucoPol and chitosan, Carbohydr. Polym. 147 (2016) 8-15, https://doi.org/10.1016/j.carbpol.2016. 03.089. 
[26] I.T. Meireles, C. Portugal, V.D. Alves, J.G. Crespo, L.M. Coelhoso, Impact of biopolyme purification on the structural characteristics and transport performance of composite polysaccharide membranes for pervaporation, J. Membr. Sci. 493 (2015) 179-187, https://doi.org/10.1016/j.memsci.2015.07.011.

[27] I.O.f.S. (ISO), ISO 10993-5:2009 biological evaluation of medical devices - part 5: tests for in vitro cytotoxicity, https://www.iso.org/standard/36406.html 2009.

[28] L. GmbH, Instructions $\mu$-plate 24 well black, https://ibidi.com/img/cms/products/ labware/plates/P_824XX_Plate_24well/IN_824XX_24well.pdf. (Accessed October 2019).

[29] I.F. Amaral, P.L. Granja, M.A. Barbosa, Chemical modification of chitosan by phosphorylation: an XPS, FT-IR and SEM study, J. Biomater. Sci. Polym. Ed. 16 (12) (2005) 1575-1593, https://doi.org/10.1163/156856205774576736.

[30] U. Siripatrawan, W. Vitchayakitti, Improving functional properties of chitosan films as active food packaging by incorporating with propolis, Food Hydrocoll. 61 (2016) 695-702, https://doi.org/10.1016/j.foodhyd.2016.06.001.

[31] L. Sun, J. Sun, L. Chen, P. Niu, X. Yang, Y. Guo, Preparation and characterization of chitosan film incorporated with thinned young apple polyphenols as an active packaging material, Carbohydr. Polym. 163 (2017) 81-91, https://doi.org/10.1016/j. carbpol.2017.01.016.

[32] J. Coates, Interpretation of infrared spectra, a practical approach, Encyclopedia of Analytical Chemistry: Applications, Theory and Instrumentation, 2006https://doi.org 10.1002/9780470027318.a5606.

[33] R.A. Mauricio-Sánchez, R Salazar, J.G. Luna-Bárcenas, A. Mendoza-Galván, FTIR spectroscopy studies on the spontaneous neutralization of chitosan acetate films by moisture conditioning, Vib. Spectrosc. 94 (2018) 1-6, https://doi.org/10.1016/j. vibspec.2017.10.005

[34] S.M. Bishop, M. Walker, A.A. Rogers, W.Y.J. Chen, Importance of moisture balance at the wound-dressing interface, J. Wound Care 12 (4) (2003) 125-128, https://doi. org/10.12968/jowc.2003.12.4.26484.

[35] H.S. Debone, P.S. Lopes, P. Severino, C.M.P. Yoshida, E.B. Souto, C.F. da Silva, Chitosan Copaiba oleoresin films for would dressing application, Int. J. Pharm. 555 (2019) 146-152, https://doi.org/10.1016/j.jijpharm.2018.11.054

[36] N.M. Hromiš, V.L. Lazić, S.L. Markov, Ž.G. Vaštag, SZ. Popović, D.Z. Šuput, N.R. Džinić, A.S. Velićanski, L.M. Popović, Optimization of chitosan biofilm properties by addition of car away essential oil and beeswax, J. Food Eng. 158 (2015) 86-93, https://doi.org 10.1016/.j.joodeng.2015.01.001.

[37] S.H. Othman, S.A.M. Edwal, N.P. Risyon, R.K. Basha, R.A. Talib, Water sorption and water permeability properties of edible film made from potato peel waste, Food Sci. Technol. 37 (2017) 63-70, https://doi.org/10.1590/1678-457x.30216.

[38] A. Zhang, L. Yang, Y. Lin, H. Lu, Y. Qiu, Y. Su, Supramolecular elastomer based on polydimethylsiloxanes (SESi) film: synthesis, characterization, biocompatibility. and its application in the context of wound dressing, J. Biomater. Sci. Polym. Ed. 24 (16) (2013) 1883-1899, https://doi.org/10.1080/09205063.2013.808151.

[39] I. Corazzari, R Nisticò, F. Turc, M.G. Faga, F. Franzoso, S. Tabasso, G. Magnacca, Advanced physico-chemical characterization of chitosan by means of TGA coupled on-line with FTIR and GCMS: thermal degradation and water adsorption capacity, Polym. Degrad. Stab. 112 (2015) 1-9, https://doi.org/10.1016/j.polymdegradstab. 2014.12.006.

[40] D. de Britto, S.P. Campana-Filho, Kinetics of the thermal degradation of chitosan, Thermochim. Acta 465 (1) (2007) 73-82, https://doi.org/10.1016/j.tca.2007.09.008.

[41] M. Kaya, S. Khadem, Y.S. Cakmak, M. Mujtaba, S. Illk, L Akyuz, Asier M. Salaberria, J. Labidi, A.H. Abdulqadir, E. Deligöz, Antioxidative and antimicrobial edible chitosan films blended with stem, leaf and seed extracts of Pistacia terebinthus for active food packaging, RSC Adv. 8 (8) (2018) 3941-3950, https://doi.org/10.1039/ c7ra12070b.

[42] J.F. Rubilar, R.M.S. Cruz, H.D. Silva, A.A. Vicente, I. Khmelinskii, M.C. Vieira, Physicomechanical properties of chitosan films with carvacrol and grape seed extract, J. Food Eng. 115 (4) (2013) 466-474, https://doi.org/10.1016/j.jfoodeng 2012.07.009.

[43] J.T. Martins, M.A. Cerqueira, A.A. Vicente, Influence of $\alpha$-tocopherol on physicochemical properties of chitosan-based films, Food Hydrocoll. 27 (1) (2012) 220-227, https://doi.org/10.1016/j.foodhyd.2011.06.011.

[44] M. Vargas, A. Albors, A. Chiralt, C. González-Martínez, Characterization of chitosanoleic acid composite films, Food Hydrocoll. 23 (2) (2009) 536-547, https://doi.org/ 10.1016/j.foodhyd.2008.02.009.

[45] C. Edwards, R. Marks, Evaluation of biomechanical properties of human skin, Clin Dermatol. 13 (4) (1995) 375-380, https://doi.org/10.1016/0738-081X(95)00078-T.

[46] F.H. Silver, LM. Siperko, G.P. Seehra, Mechanobiology of force transduction in dermal tissue, Skin Res. Technol. 9 (1) (2003) 3-23, https://doi.org/10.1034/j.16000846.2003.00358.x.

[47] C. Wiegand, U. Schönfelder, M. Abel, P. Ruth, M. Kaatz, U.C. Hipler, Protease and proinflammatory cytokine concentrations are elevated in chronic compared to acute wounds and can be modulated by collagen type I in vitro, Arch. Dermatol. Res. 302 (6) (2010) 419-428, https://doi.org/10.1007/s00403-009-1011-1.

[48] A. Ribeiro, T. Matamá, C.F. Cruz, A.C. Gomes, A.M. Cavaco-Paulo, Potential of human $\gamma \mathrm{D}$-crystallin for hair damage repair: insights into the mechanical properties and biocompatibility, Int. J. Cosmet. Sci. 35 (5) (2013) 458-466, https://doi.org/10 1111 /ics. 12065

[49] K. Takei, A. Hashimoto-Hachiya, M. Takahara, G. Tsuji, T. Nakahara, M. Furue, Cynaropicrin attenuates UVB-induced oxidative stress via the AhR-Nrf2-Nqo1 pathway, Toxicol, Lett. 234 (2) (2015) 74-80, https://doi.org/10.1016/j.toxlet. 2015.02.007.

[50] L.E. Tracy, R.A. Minasian, E.J. Caterson, Extracellular matrix and dermal fibroblast function in the healing wound, Adv. Wound Care 5 (3) (2016) 119-136, https:// doi.org/10.1089/wound.2014.0561.

[51] L. Greenspan, Humidity fixed points of binary saturated aqueous solutions, J. Res. Natl. Bur. Stand. 81 (1) (1977) 89-96, https://doi.org/10.6028/jres.081a.011.

[52] T. Vanden Berghe, M. Kalai, G. Denecker, A. Meeus, X. Saelens, P. Vandenabeele, Necrosis is associated with IL-6 production but apoptosis is not, Cell. Signal. 18 (3) (2006) 328-335, https://doi.org/10.1016/j.cellsig.2005.05.003. 